\title{
The impact of lateral carbon fluxes on the European carbon balance
}

\author{
P. Ciais ${ }^{1}$, A. V. Borges ${ }^{2}$, G. Abril ${ }^{3}$, M. Meybeck ${ }^{4}$, G. Folberth ${ }^{5}$, D. Hauglustaine ${ }^{1}$, and I. A. Janssens ${ }^{6}$ \\ ${ }^{1}$ Laboratoire des Sciences du Climat et de l'Environnement, IPSL/LSCE CEA-CNRS-UVSQ, Gif sur Yvette, France \\ ${ }^{2}$ Chemical Oceanography Unit, University of Liège, Belgium \\ ${ }^{3}$ Environnements et Paléoenvironnements OCéaniques, Université de Bordeaux 1. CNRS-UMR 5805, Avenue des Facultés, \\ Talence, France \\ ${ }^{4}$ SISYPHE, Université Paris VI Jussieu, Paris, France \\ ${ }^{5}$ School of Earth and Ocean Science, University of Victoria, Victoria, Canada \\ ${ }^{6}$ Department of Biology, Universiteit Antwerpen, Antwerpen, Belgium
}

Received: 5 May 2006 - Published in Biogeosciences Discuss.: 22 September 2006

Revised: 30 May 2007 - Accepted: 23 July 2008 - Published: 5 September 2008

\begin{abstract}
To date, little is known about the impact of processes which cause lateral carbon fluxes over continents, and from continents to oceans on the $\mathrm{CO}_{2}$ - and carbon budgets at local, regional and continental scales. Lateral carbon fluxes contribute to regional carbon budgets as follows: Ecosystem $\mathrm{CO}_{2}$ sink=Ecosystem carbon accumulation+Lateral carbon fluxes. We estimated the contribution of wood and food product trade, of emission and oxidation of reduced carbon species, and of river erosion and transport as lateral carbon fluxes to the carbon balance of Europe (EU-25). The analysis is completed by new estimates of the carbon fluxes of coastal seas. We estimated that lateral transport (all processes combined) is a flux of $165 \mathrm{Tg} \mathrm{C} \mathrm{yr}^{-1}$ at the scale of EU-25. The magnitude of lateral transport is thus comparable to current estimates of carbon accumulation in European forests. The main process contributing to the total lateral flux out of Europe is the flux of reduced carbon compounds, corresponding to the sum of non- $\mathrm{CO}_{2}$ gaseous species $\left(\mathrm{CH}_{4}, \mathrm{CO}\right.$, hydrocarbons, ...) emitted by ecosystems and exported out of the European boundary layer by the large scale atmospheric circulation.
\end{abstract}

\section{Introduction}

Lateral carbon transport moves carbon away from where $\mathrm{CO}_{2}$ is withdrawn from the atmosphere. This induces differences between regional changes in carbon stocks and regional $\mathrm{CO}_{2}$ fluxes (Tans et al., 1995; Sarmiento et al., 1992).

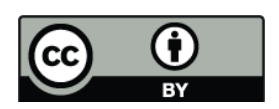

Correspondence to: P. Ciais (philippe.ciais@cea.fr)
Lateral carbon transport contributes to the carbon budget of ecosystems as follows:

Ecosystem $\mathrm{CO}_{2}$ sink=Ecosystem carbon accumulation + Lateral carbon flux.

Comparing $\mathrm{CO}_{2}$ fluxes resulting from atmospheric inversion models with bottom-up carbon flux estimates (Pacala et al., 2001; Janssens et al., 2003; Peylin et al., 2005), one may expect differences explained by lateral carbon transport. Some bottom-up approaches (e.g. forest biomass inventories) estimate carbon stock changes, while some directly measure $\mathrm{CO}_{2}$ fluxes (e.g. eddy covariance flux towers). This paper has three main goals. The first one is to describe the mechanisms of lateral carbon transport and some of their implications for regional carbon budgets. The second goal is to quantify the flux of carbon displaced within and from the European territory (here the EU-25), and to place it in the context of atmospheric inversion results. The third goal is to provide geospatial estimates of the $\mathrm{CO}_{2}$ fluxes associated with lateral processes, whenever this is possible.

We consider three processes linking $\mathrm{CO}_{2}$ fluxes with lateral carbon transport either within the EU-25 area or across its boundaries. These processes are (1) the trade of food, feed and wood products (Ciais, et al., 2006; Imhoff, et al., 2004), (2) the emissions of reduced atmospheric carbon compounds such as $\mathrm{CO}, \mathrm{CH}_{4}$, terpenes, and isoprene by ecosystems and human activities, which get transported by winds and oxidized by chemical reactions in the global atmosphere outside Europe (Enting et al., 1991; Folberth et al., 2005; Suntharalingam et al., 2005), and (3) the river transport of carbon from land to the ocean (Aumont et al., 2001; Meybeck 1987). In addition, $\mathrm{CO}_{2}$ fluxes in coastal seas (Borges et al., 2006) are estimated. This exchange of atmospheric $\mathrm{CO}_{2}$ by coastal

Published by Copernicus Publications on behalf of the European Geosciences Union. 
Plant $\mathrm{CO}_{2}$ uptake (C harvested in crop and wood products)

(1)

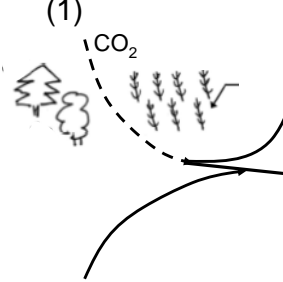

(2)

Imports

Exports
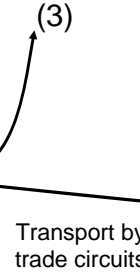

trade circuits

(a)

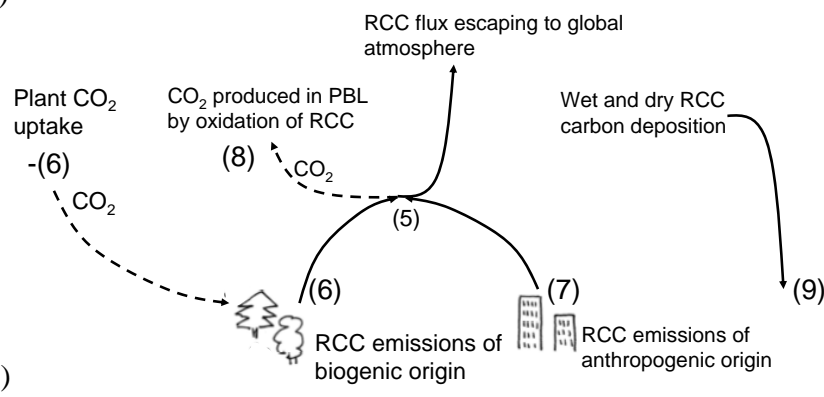

Plant $\mathrm{CO}_{2}$ uptake

\section{(10)}

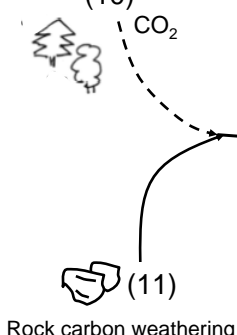

(c)

Rock carbon weathering

Fig. 1. Carbon cycle loops involving lateral transport. Numbers associated to each flux correspond to data in Table 2. The associated sources/sinks of atmospheric $\mathrm{CO}_{2}$ are given by dashed lines, and the fluxes of carbon are given by solid lines. (a) Lateral transport by trade of crop and wood products. (b) Lateral transport by reduced carbon compounds (RCC) emissions and atmospheric chemistry and transport. (c) Lateral transport by river transport coupled to rock weathering.

seas does not per se originate from a lateral carbon flux, but it is considered here as a necessary flux component to reconcile large-scale $\mathrm{CO}_{2}$ flux atmospheric inversion results with bottom-up inventory data. The first four sections below treat each lateral transport process separately. The discussion section summarizes the contribution of the different processes to the carbon balance of Europe. By convention, all fluxes of carbon gained by the continent are sinks for the atmosphere and counted negatively, while carbon lost by the continent is counted as a positive flux.

\section{Crop and forest products trade}

\subsection{Food and feed products}

Cultivated lands are long-term net sinks of atmospheric $\mathrm{CO}_{2}$ because carbon incorporated into biomass is harvested and removed from ecosystems to supply human or animal consumption (Fig. 1a). The consumption of food or feed products releases $\mathrm{CO}_{2}$ back to the atmosphere, away from ecosystems. Over the globe, the lateral transport of carbon in food products is neutral for the atmosphere, given the fact that storage of food products is negligible compared to harvested fluxes. At the regional scale, croplands are net $\mathrm{CO}_{2}$ sinks (as confirmed by year-round eddy-covariance measurements, e.g. Anthoni et al., 2004) while populated areas where food is consumed are net $\mathrm{CO}_{2}$ sources. At the continental level, international trade of crop products also intervenes into the net carbon balance.

We analyzed the agricultural statistics from FAO (2004) to infer harvest, lateral carbon transport and subsequent $\mathrm{CO}_{2}$ land-atmosphere fluxes caused by food trading. We found that cereals, essentially maize, wheat and barley, are responsible for nearly all of the $\mathrm{CO}_{2}$ sink in European croplands. In contrast, the $\mathrm{CO}_{2}$ source derived from food consumption originates from a more diverse mix of crop products. From the perspective of individual countries, the situation is contrasted (Fig. 2). The largest $\mathrm{CO}_{2}$ sink associated with the

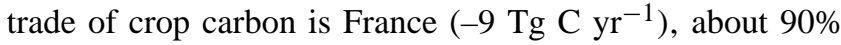
of the total European sink for that process. The largest $\mathrm{CO}_{2}$ sources are Portugal, Belgium, Netherlands, Italy and Spain (altogether $22 \mathrm{Tg} \mathrm{C} \mathrm{yr}^{-1}$ ). Other countries are approximately neutral. We found no relationship between harvest and the net carbon balance in each country with regards to food trade. At the continental level, Europe imports more carbon in food and feed than it exports, thus being a net $\mathrm{CO}_{2}$ source to the atmosphere of $24 \mathrm{Tg} \mathrm{C} \mathrm{yr}^{-1}$, about $2 \%$ of EU-25 fossil fuel $\mathrm{CO}_{2}$ emissions.

The patterns of $\mathrm{CO}_{2}$ fluxes induced by trade is mapped using geospatial information on (1) crop varieties (Ramankutty et al., 1998), (2) human population and, (3) housed poultry, pigs and cattle populations. Statistical data on feedstuff and food product harvest and trade (FAO, 2004) is converted to a geospatial dataset on a $1^{\circ}$ by $1^{\circ}$ grid, using the same methodology as in Ciais et al. (2006). Crop biomass data are converted into dry biomass and into carbon using crop-specific conversion factors (Goudriaan et al., 2001). The results are shown in Fig. 3. Agricultural plains with intensive cultivation (northern France, southern England, Hungarian plains, Po valley in Italy) are annual net sinks of $\mathrm{CO}_{2}$, with uptake rates reaching up to $100 \mathrm{~g} \mathrm{C} \mathrm{m}^{-2} \mathrm{yr}^{-1}$. Locally, this $\mathrm{CO}_{2}$ sink is larger than the mean European forest uptake flux (70 $\mathrm{g} \mathrm{C} \mathrm{m}^{-2} \mathrm{yr}^{-1}$ in Janssens et al., 2003), which is not surprising given the slightly higher NPP and harvest index (ratio of yield to above-ground NPP) of crops compared to trees. 


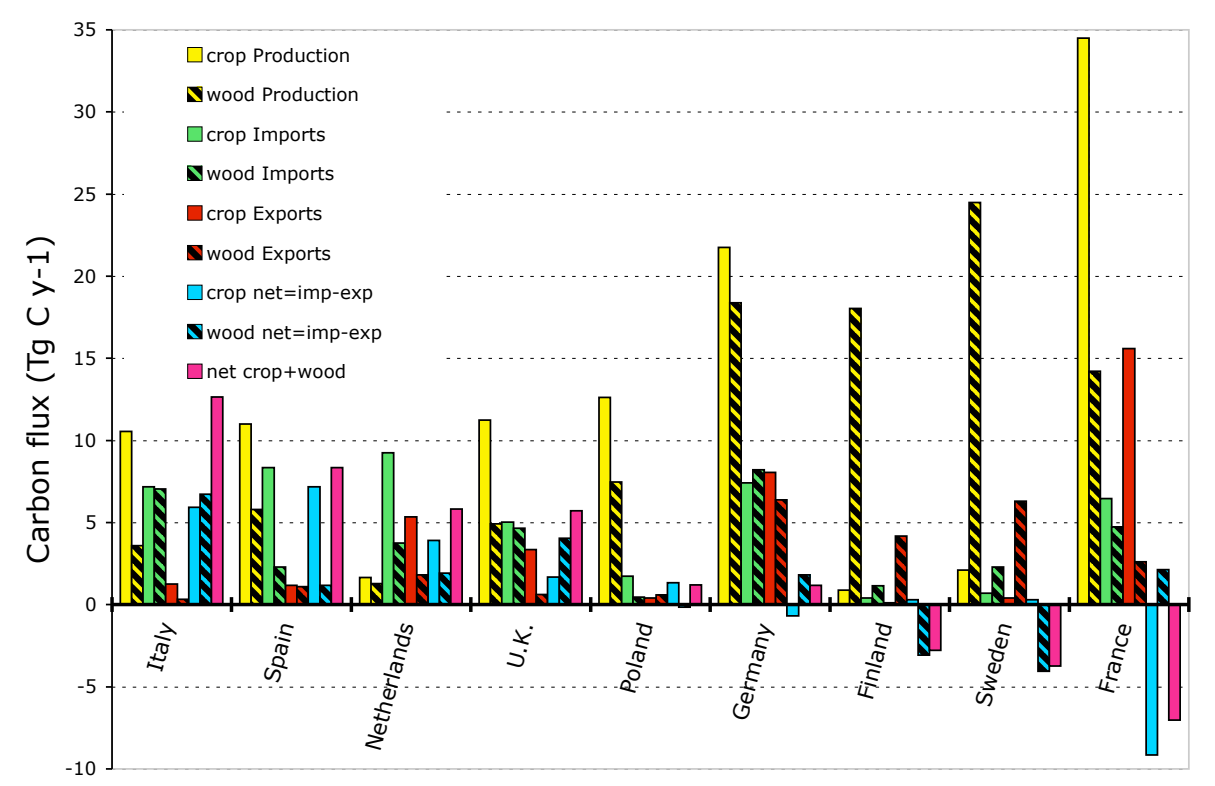

Fig. 2. Carbon fluxes associated with harvest and trade in various countries. Production (=harvest) requires plant $\mathrm{CO}_{2}$ uptake to form biomass. Imported products are oxidized into $\mathrm{CO}_{2}$, making a net $\mathrm{CO}_{2}$ source in the importing country. Exported products require plant $\mathrm{CO}_{2}$ uptake to form crop and wood biomass (included in production), making a $\mathrm{CO}_{2}$ sink in the exporting country. The net flux is the balance between $\mathrm{CO}_{2}$ sources and sinks (see Fig. 1a). convention, sources of $\mathrm{CO}_{2}$ to the atmosphere are positive. By convention, sources of $\mathrm{CO}_{2}$ to the atmosphere are positive.

(a) Sink for exported wood

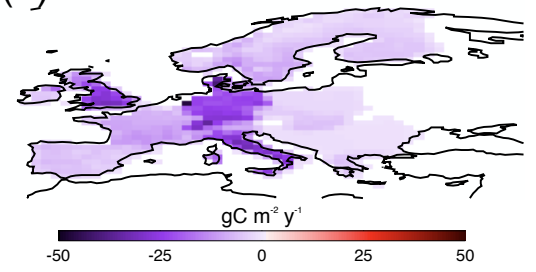

(c) Sink for exported food \& feed

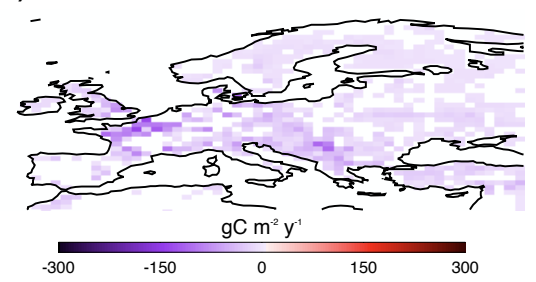

(b) Source of imported wood use

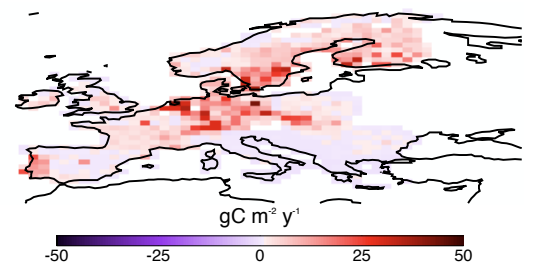

(d) Source of imported food \& feed

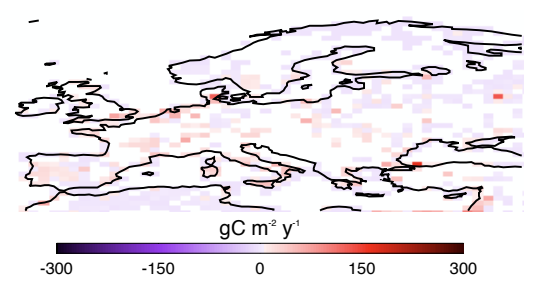

Fig. 3. Spatial patterns of trade induced $\mathrm{CO}_{2}$ fluxes with the atmosphere. Sources of $\mathrm{CO}_{2}$ are positive and sinks are negative (in $\mathrm{g} \mathrm{C} \mathrm{m}^{-2} \mathrm{y}^{-1}$ ). (a-b) $\mathrm{CO}_{2}$ fluxes associated with wood products export and import. (c-d) $\mathrm{CO}_{2}$ fluxes associated with food and feed products export and import. 
Table 1. Component fluxes of the cycle of non- $\mathrm{CO}_{2}$ reduced carbon compounds (RCC) over the European continent and its boundary layer, an area bounded by $32 \mathrm{~N}$ and $73 \mathrm{~N}$ in latitude and $-10 \mathrm{~W}$ and $40 \mathrm{E}$ in longitude. Sources to the atmosphere are counted $>0$ and sinks $<0$. Fluxes are estimated using a global chemistry transport model. Units are $\mathrm{Tg} \mathrm{C} \mathrm{yr}^{-1}$.

\begin{tabular}{lr}
\hline RCC Reduced carbon compounds emissions & ${\mathrm{Tg} \mathrm{C} \mathrm{yr}^{-1}}^{\mathrm{CH}_{4} \text { emissions }}$ \\
$\mathrm{CO}$ emissions & 60.0 \\
BVOC emissions & 82.0 \\
Other VOC emissions & 27.0 \\
Total & 15.5 \\
\hline $\mathrm{CO}_{2}$ flux produced in PBL from RCC oxidation & 184.5 \\
\hline Boundary layer & \\
Free troposphere & 25.7 \\
Total & 19.3 \\
\hline Wet and dry RCC carbon deposition over Europe & 45.0 \\
\hline Surface dry deposition & -12.0 \\
Wet deposition & -9.6 \\
Total carbon deposited & -21.6 \\
\hline
\end{tabular}

Urban regions in Fig. 3, and intensive farming regions, emit $\mathrm{CO}_{2}$ to the atmosphere at a rate of $50 \mathrm{~g} \mathrm{C} \mathrm{m}^{-2} \mathrm{yr}^{-1}$.

There are uncertainties on these maps. Using statistics at the country level may smooth out the fields. For instance, feedstuff consumption by farm animals is distributed at the country level according to animal population maps, while in reality animals may have different regional reliance on feedstuff. National harvest of crop biomass is distributed evenly according to the area of each crop variety, neglecting regional differences in yields caused by soil fertility or climate gradients. Finally, food consumption is assumed to be a $\mathrm{CO}_{2}$ source distributed according to human population, thereby neglecting the transport of organic carbon to sewage water and rivers.

\subsection{Forest products}

We consider forest products from coniferous and nonconiferous trees: industrial round wood, sawn wood, wood panels and paper, as listed in the FAO (2004) database. Wood product data in volumetric units are converted to carbon weight units using a mean wood density of $500 \mathrm{~kg} \mathrm{~m}-3$, and a 0.45 carbon fraction in dry biomass, respectively. Sweden and Finland export more carbon in wood than they import, thus being net sinks of atmospheric $\mathrm{CO}_{2}$ of $-3 \mathrm{Tg} \mathrm{C} \mathrm{yr}^{-1}$ and $-4 \mathrm{Tg} \mathrm{C} \mathrm{yr}^{-1}$ respectively (Fig. 2). Nearly all other countries are net $\mathrm{CO}_{2}$ sources to the atmosphere with respect to wood products trade. The largest sources are in Italy $\left(6 \mathrm{Tg} \mathrm{C} \mathrm{yr}^{-1}\right)$, Spain, the Netherlands and the UK. Countries that export food products typically also export wood products (except for Nordic countries) and vice versa. At the EU-25 level, imports of wood products currentlysions exceed exports, in-

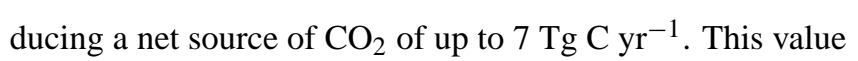
is likely to be a maximum estimate because it assumes that wood products are decomposed into $\mathrm{CO}_{2}$ instantly, neglecting storage. Using the mean residence times of wood products of Liski et al. (2005), typically 30 years for spruce wood and 40 years for oak sawn wood, we estimate that on a 10 years horizon, the trade of wood products results in a net source of $\mathrm{CO}_{2}$ to the atmosphere of $2 \mathrm{Tg} \mathrm{C} \mathrm{yr}^{-1}$ only, while the remaining $5 \mathrm{Tg} \mathrm{C} \mathrm{yr}^{-1}$ is temporarily stored in product pools.

To map the $\mathrm{CO}_{2}$ fluxes from forest product trade, we converted the country-level data (FAO, 2004) into a geospatial dataset on a $1^{\circ} \times 1^{\circ}$ grid using a remote-sensing driven NPP model (Lafont, et al., 2002) and a forest cover map of Europe (CORINE Land cover, 2000). The geographical distribution of the $\mathrm{CO}_{2}$ source due to the decay of wood products is assumed to follow population density (i.e. assuming that landfills are distributed like population density). The results are shown in Fig. 3.

There are large uncertainties in these maps. First, forests with high greenness (NDVI) wil not necessarily have the largest biomass, nor wood production. For instance, the NDVI vegetation index is well known to saturate at high Leaf Area Index values, although Myneni et al. (2001) showed a positive correlation between NDVI and biomass over a wide range of forests. Further, the areas where $\mathrm{CO}_{2}$ is released by decaying wood-products may differ in their geographic location from the actual population density distribution (e.g. depending on regional practice for using wood as a construction material).

\section{Reduced carbon compounds}

\subsection{Surface emissions}

Ecosystems and anthropogenic activities emit non- $\mathrm{CO}_{2}$ reduced carbon compounds, hereafter called RCC. RCC are the sum of $\mathrm{CO}, \mathrm{CH}_{4}$, biogenic volatile organic compounds (BVOC such as isoprene, terpene), and anthropogenic volatile organic compounds (VOC). These species are reactive and their atmospheric lifetimes vary over several orders of magnitude, from 9 years for methane, down to a mere few hours in the case of terpene. Although the oxidation sequence of an RCC can be complex, the main end product is $\mathrm{CO}_{2}$. The global RCC flux from ecosystems is small compared to photosynthesis or respiration. It can, however, become significant compared to the net carbon balance of an ecosystem (Kesselmeier et al., 2005). If the objective of a study is to determine the $\mathrm{CO}_{2}$ flux of Europe by inverse modeling of $\mathrm{CO}_{2}$ concentration, then RCC emissions can rightfully be ignored. On the other hand, if the objective is to determine the carbon flux of Europe, the RCC flux must then be added as a correction to the $\mathrm{CO}_{2}$ flux calculated by inversions. 


\section{2 $\mathrm{CO}_{2}$ production in the atmosphere}

The lifetime of atmospheric RCC compounds with respect to their chemical sink in the atmosphere can easily exceed typical boundary-layer transport time scales. The carbon carried by RCC can thus be released as $\mathrm{CO}_{2}$ away from surface emissions (Fig. 1b). Table 1 shows that the total EU-25 emissions of RCC are $185 \mathrm{Tg} \mathrm{Cyr}^{-1}$. A small fraction of these emissions $(14 \%)$ is transformed into $\mathrm{CO}_{2}$ in the boundary layer, very shortly after emission (Fig. $1 \mathrm{~b}$ and Table 1 ). We estimated the $\mathrm{CO}_{2}$ production from RCC using a global 3-D chemistry transport model (Folberth, et al., 2005, Hauglustaine et al., 2004). This model accounts for two major oxidation channels of RCC: (1) the oxidation of primary $\mathrm{CO}$ and of secondary $\mathrm{CO}$ from the oxidation of $\mathrm{CH}_{4}$ and Volatile Organic Compounds (VOC), and (2) the direct oxidation of peroxy-radicals carbon into $\mathrm{CO}_{2}$. An additional minor channel corresponds to the direct ozonolysis of alkenoid compounds into $\mathrm{CO}_{2}$ and is also taken into account. The total 'photochemical' $\mathrm{CO}_{2}$ production from $\mathrm{RCC}$ in the atmospheric column over Europe amounts to $45 \mathrm{Tg} \mathrm{C} \mathrm{yr}^{-1}$ and $57 \%$ of this flux ( $26 \mathrm{Tg} \mathrm{C} \mathrm{yr}^{-1}$ ) occurs in the boundary layer, as reported in Table 1 . About $90 \%$ of the photochemical $\mathrm{CO}_{2}$ production comes from $\mathrm{CO}$ oxidation by hydroxyl radicals $(\mathrm{OH})$. A map of RCC deposition and emission is given in Fig. 4.

3.3 Surface deposition of carbon and impact on the net carbon balance

A gain of carbon by the European surface occurs via the dry surface deposition processes and the wet scavenging by precipitation (Fig. 1b). This sink amounts to $22 \mathrm{Tg} \mathrm{C} \mathrm{yr}^{-1}$ (Table 1). The net effect of RCC on the European carbon flux can be estimated by taking the difference between surface emissions (carbon source) and the photosynthetic uptake of $\mathrm{CO}_{2}$ from which the biogenic VOC emissions are derived (carbon sink) plus the dry and wet RCC deposition flux (carbon sink) must be derived (Fig. 1b). We estimate a net carbon loss to the atmosphere of $76 \mathrm{Tg} \mathrm{C} \mathrm{yr}^{-1}$ (Table 2). The impact of RCC compounds on the European $\mathrm{CO}_{2}$ flux is different. It is the difference between the photochemical flux of $\mathrm{CO}_{2}$ into the boundary layer (oxidation of RCC) and the $\mathrm{CO}_{2}$ uptake photosynthesis which fuels the biogenic RCC emissions. We note a corresponding net $\mathrm{CO}_{2}$ sink of $61 \mathrm{Tg} \mathrm{C} \mathrm{yr}^{-1}$ (Table 2).

\section{Riverine carbon transport}

4.1 Processes controlling the transport of atmospheric carbon by rivers

Rivers (streams, lakes, river main stems, floodplains and estuaries) transport carbon laterally from the land to the ocean, and vertically as $\mathrm{CO}_{2}$ degassing to the atmosphere and as carbon burial in sediments (Fig. 1c). Rivers transport carbon in dissolved and particulate organic forms (DOC, POC) and under inorganic forms (DIC, PIC and dissolved $\mathrm{CO}_{2}$ ). The source and sink processes of river carbon in natural conditions are: (1) wetlands and peat drainage, (2) soil leaching and erosion, and (3) chemical weathering of soil minerals. This carbon is originally taken up from the atmosphere by photosynthesis $\left(\mathrm{CO}_{2}+\mathrm{H}_{2} \mathrm{O}\right.$ $\left.>\mathrm{CH}_{2} \mathrm{O}+\mathrm{O}_{2}\right)$, or by direct carbonate rock weathering $\left(\mathrm{CO}_{2}+\mathrm{H}_{2} \mathrm{O}+\mathrm{MCO}_{3} \rightarrow 2 \mathrm{HCO}_{3}^{-}+\mathrm{M}^{2+}\right)$ or silicate rock weathering $\left(2 \mathrm{CO}_{2}+\mathrm{H}_{2} \mathrm{O}+\mathrm{MSiO}_{3} \rightarrow 2 \mathrm{HCO}_{3}^{-}+\mathrm{M}^{2+}+\mathrm{SiO}_{2}\right)$. During the weathering of silicate rocks $100 \%$ of river DIC originates from the atmosphere, but during weathering of carbonate rocks, only half of the DIC originates from the atmosphere, and half derives from fossil carbonates stored in rocks. Therefore the nature and age of river carbon species is very different (Meybeck 1993, 2005). Particulate inorganic carbon (PIC) is derived from mechanical erosion. While being transported downstream to the coast, PIC is gradually trapped in lowlands, floodplains, lakes, estuaries and on the continental shelf. This relocation of PIC does not generally affect the $\mathrm{CO}_{2}$ cycle. Also, under specific arid conditions and high $\mathrm{pH}$, some DIC may precipitate on its way to the sea as calcite in soils and sediments.

Factors controlling river export of atmospheric carbon (DOC+POC+atmospheric derived DIC) are first river runoff, then rock type via the occurrence of carbonates, and finally the presence of wetlands and large lakes. A preliminary comparison of river carbon fluxes in northern, central and southern Europe shows strong regional contrasts. Northern catchments show high DOC export, but most POC is trapped in lakes which cover 5-20\% of these basins (Meybeck et al., 2005). The age of this DOC derived from wetlands and peat bogs typically ranges from 100 to 6000 years. Southern catchments show DIC derived from the atmosphere as the dominant form of river carbon. Central European catchments are intermediate, with carbon fluxes depending on river runoff and rock type.

\subsection{Human perturbation of river carbon transport}

Human intervention in river catchments may substantially modify river carbon transport (Fig. 5b). The exploitation of peat bogs generally increases DOC contents in head waters (Fig. 5a-b). Increased soil erosion by agricultural practices increases the POC inputs. Untreated organic waste water (Fig. 5b-c) and eutrophication of rivers and lakes (Fig. 5b, 
Table 2. Carbon fluxes and $\mathrm{CO}_{2}$ fluxes caused by lateral transport processes. The European "continent" is defined as including its atmospheric boundary layer and its inner estuaries. A flux lost by the European continent is counted $>0$, and a carbon gain is counted $<0$. An uncertainty index of each estimate is given in the right hand column (low uncertainty +++ , high uncertainty + ). The numbers in parenthesis associated to each flux correspond to those shown in Fig. 1. By convention, sources for atmosphere are shown as positive values whereas sinks are shown as negative values.

\begin{tabular}{|c|c|c|}
\hline Estimated flux $\left(\mathrm{Tg} \mathrm{C} \mathrm{yr}^{-1}\right)$ & & Quality index \\
\hline \multicolumn{3}{|l|}{ Crop and forest products trade } \\
\hline Ecosystem $\mathrm{CO}_{2}$ sink located in crop+wood product (1) & -250 & +++ \\
\hline Imports of crop + wood products $(2)^{\mathrm{a}}$ & 110 & +++ \\
\hline Export of crop + wood products $(3)^{b}$ & -81 & +++ \\
\hline Storage in wood products (4) & 5 & + \\
\hline Net $\mathrm{CO}_{2}$ release by oxidation of products $=-(2)+(1)+(3)-(4)^{\mathrm{c}}$ & 274 & ++ \\
\hline Total net $\mathrm{CO}_{2}$ flux of river transport & 24 & ++ \\
\hline Total net carbon flux of river transport & 24 & ++ \\
\hline \multicolumn{3}{|l|}{ Atmospheric reduced carbon compounds } \\
\hline RCC total emissions (5) & 185 & ++ \\
\hline RCC emissions of biogenic origin (6) ${ }^{d}$ & 87 & ++ \\
\hline RCC emissions of anthropogenic origin (7) & 98 & ++ \\
\hline $\mathrm{CO}_{2}$ flux produced in PBL from RCC oxidation (8) & 26 & ++ \\
\hline RCC flux escaping to the global atmosphere $=(5)-(8)$ & 159 & ++ \\
\hline Wet and dry RCC carbon deposition=(9) & -22 & + \\
\hline Ecosystem $\mathrm{CO}_{2}$ sink required to compensate for (6) ${ }^{\mathrm{d}}$ & -87 & + \\
\hline Total net $\mathrm{CO}_{2}$ flux of river transport & -61 & + \\
\hline Total net carbon flux of river transport ${ }^{\mathrm{d}}$ & 76 & + \\
\hline \multicolumn{3}{|l|}{ River carbon transport } \\
\hline Ecosystem $\mathrm{CO}_{2}$ sink which is transported by rivers (10) & -160 & + \\
\hline Rock $\mathrm{C}$ weathering which is transported by rivers (11) & -16 & + \\
\hline $\mathrm{CO}_{2}$ outgassing in rivers $(12)$ & 90 & ++ \\
\hline Carbon burial in lakes, dams, estuarine sediments (13) & -33 & ++ \\
\hline Net transport to estuaries $(14)^{\mathrm{f}}$ & 53 & +++ \\
\hline $\mathrm{CO}_{2}$ outgassing in estuaries (15) & 10 to 20 & + \\
\hline Total $\mathrm{CO}_{2}$ outgassing $=(12)+(15)^{\mathrm{e}}$ & 100 to 110 & \\
\hline Net carbon transport to ocean $=(14)-(15)^{f}$ & 43 to 33 & \\
\hline Total net $\mathrm{CO}_{2}$ flux of river transport & -60 to -50 & \\
\hline Total net carbon flux of river transport & -113 & \\
\hline \multicolumn{3}{|l|}{ Coastal seas } \\
\hline Uptake of atmospheric $\mathrm{CO}_{2}$ by coastal seas & -68 & ++ \\
\hline \multicolumn{3}{|l|}{ Grand total including coastal seas } \\
\hline Net European $\mathrm{CO}_{2}$ flux & -165 to -155 & + \\
\hline Net European carbon flux & -81 & + \\
\hline
\end{tabular}

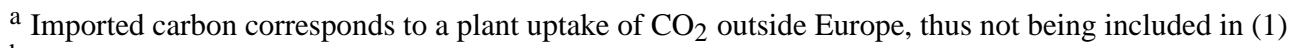

${ }^{\mathrm{b}}$ Exported carbon corresponds to a plant uptake of $\mathrm{CO}_{2}$ inside Europe, thus being included in (1)

c Assumes that the decomposition of crop and wood products generates $\mathrm{CO}_{2}$ which is emitted to the atmosphere

$\mathrm{d}$ Assumes that $100 \%$ of biogenic RCC emissions comprising terpenes, methanol, methane, are formed by plant carbon derived from photosynthesis, causing a compensating sink of $\mathrm{CO}_{2}$.

e Established for an area of $8.16 \mathrm{Mkm}^{2}$, including the Barentz sea and Black Sea river catchments.

${ }^{\mathrm{f}}$ Although this carbon is not lost by the continent to the atmosphere as $\mathrm{CO}_{2}$, but lost to estuaries in the case of (14) and to coastal oceans in the case of (14)-(15), it is counted as source $(>0)$ in the table. 
(a)

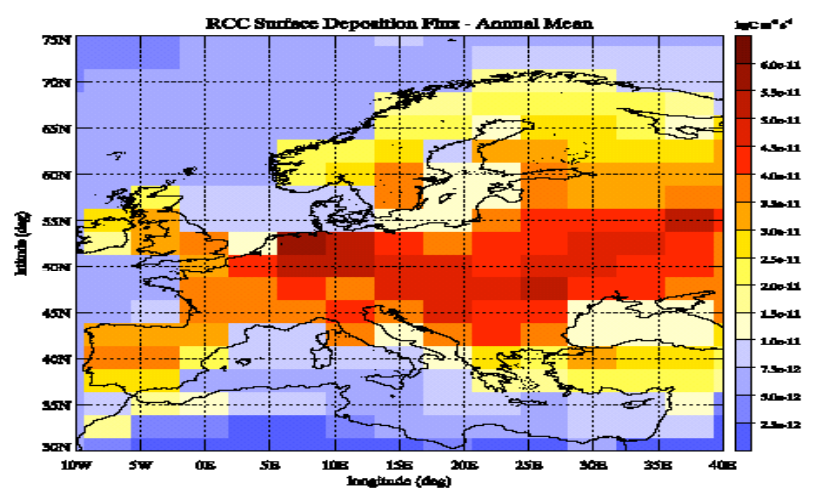

(b)

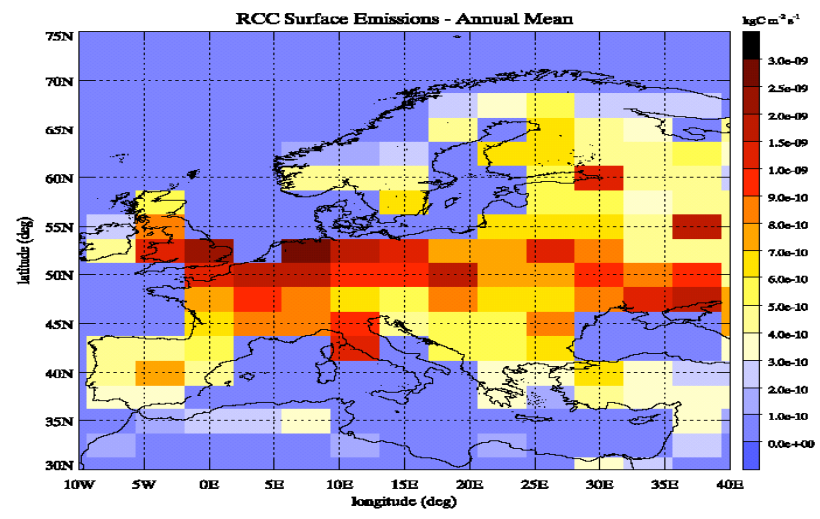

Fig. 4. (a) Spatial patterns of the surface deposition (sink) of carbon from reduced carbon compounds (RCC). (b) Patterns of reduced carbon compounds emissions to the atmosphere from antropogenic and biospheric sources.

d) are additional sources of very labile DOC and POC. The ages of these carbon species are highly variable (a few days for river algal carbon to 1000 years for peat DOC). The $\mathrm{CO}_{2}$ evasion from freshwaters strongly depends on the reactivity of the organic carbon carried by rivers. During the 1970's, when rivers were receiving untreated waste water, river respiration $R$ exceeded river production $P$ (Gross primary production), resulting in eutrophication and in a net $\mathrm{CO}_{2}$ source to the atmosphere (Kempe, 1984). Nowadays, due to waste water treatment, the same river may have multiple changes of $P / R$ ratio from headwaters to estuary, as observed for the Scheldt and Seine rivers (Meybeck et al., 2005).

As part of human activity, river damming and irrigation control the carbon fluxes to oceans. Reservoirs store up to 99\% of particulate river material (Vörösmarty et al., 2003) including POC and may degrade DOC and retain part of DIC as calcite precipitation. Irrigation canals continuously transfer river carbon to agricultural soils. In Southern Europe, the export of riverine carbon to the ocean has decreased in most rivers (e.g. by $40 \%$ for the Ebro). However, the impact of
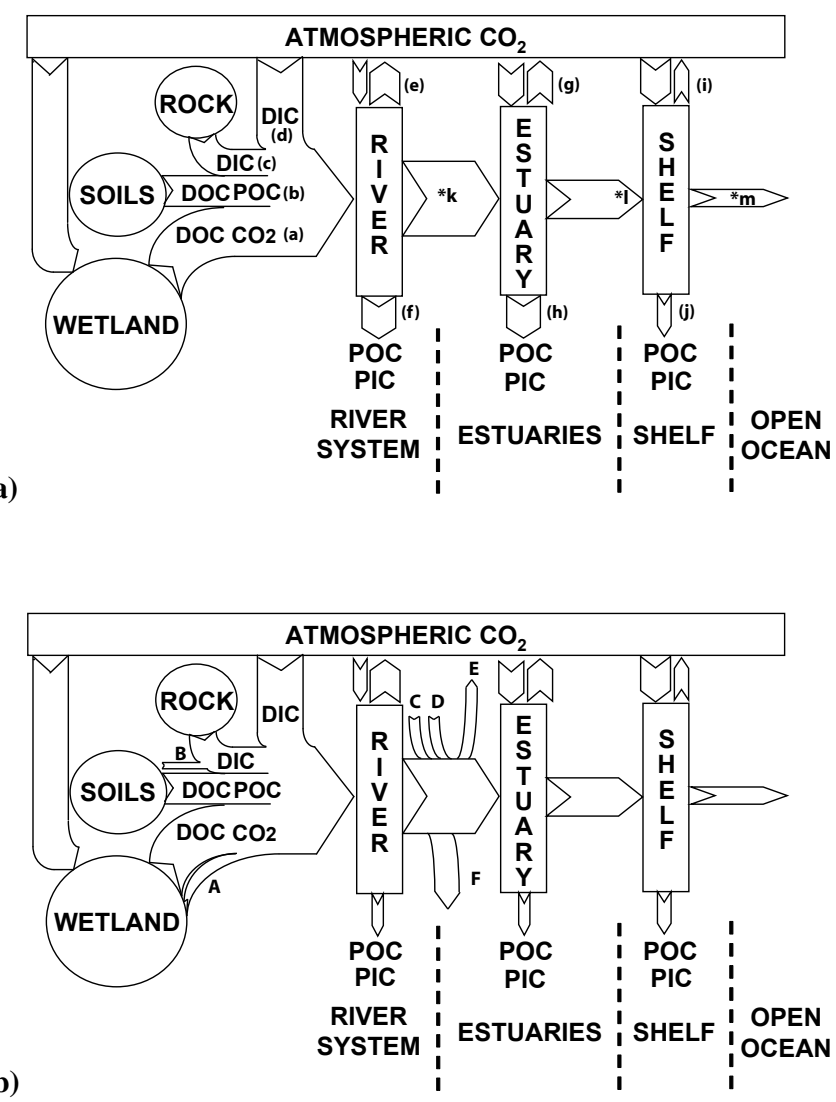

Fig. 5. Transport of river carbon along the aquatic continuum. (a) Under natural conditions. (b) With multiple human impacts. See text for indications.

water withdrawal for irrigation on river carbon fluxes to the Mediterranean Sea or the Portuguese coast is unknown because the last gaging and water quality stations are located upstream of the major irrigation areas (e.g. deltas of Ebro, Rhone, Axios) as noted by Ludwig et al. (2004).

\section{3 $\mathrm{CO}_{2}$ fluxes from rivers and freshwater systems}

In the EU-25, freshwater systems are net sources of $\mathrm{CO}_{2}$ to the atmosphere. Except for a few cases occurring seasonally, $\mathrm{CO}_{2}$ super-saturation in the water generally prevails in streams (Hope et al., 2001; Billet et al., 2004), lakes (Cole et al., 1994), rivers (Kempe, 1982; Jones and Mulholland 1998; Abril et al., 2000; Cole and Caraco 2002), and estuaries (Frankignoulle et al., 1998; Abril and Borges 2004). Such high $\mathrm{CO}_{2}$ concentrations in continental waters correspond to either to $\mathrm{CO}_{2}$ derived from soil respiration, followed by runoff and riparian transport, or to $\mathrm{CO}_{2}$ derived from oxidation of terrestrial organic carbon in the aquatic system itself, by microbial respiration and photochemistry (Granéli et al., 1996; Jones and Mulholland, 1998; Abril and Borges, 2004; Gazeau et al., 2005). Temperate rivers in western Europe show a positive $p \mathrm{CO}_{2}$ vs. DOC relationship (Fig. 6) 


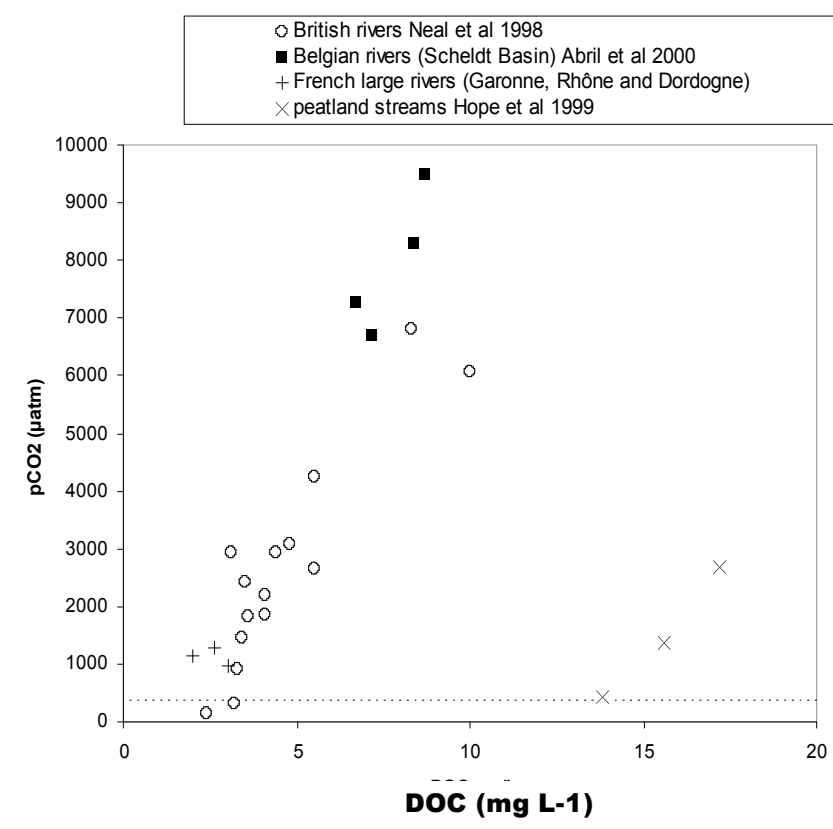

Fig. 6. Relationship between $p \mathrm{CO}_{2}$ and DOC in selected European river systems. British lowland rivers from Neal et al., 1998, Belgian lowland rivers (Scheldt watershed) from Abril et al., 2000, Large French rivers from Abril and Commarieu (Unpublished) (Garonne and Dordogne), and from Aucour et al., 1999 and Sempéré et al., 2000 (Rhône), Scottish Upland peat streams from Hope et al., 2001. The dotted line marks the atmospheric $p \mathrm{CO}_{2}$.

as a result of anthropogenic loads increasing the DOC, enhancing aquatic respiration, and increasing $p \mathrm{CO}_{2}$ (Neal et al., 1998; Abril et al., 2000). In contrast, northern headwaters (e.g. Scottish peatlands) show low $p \mathrm{CO}_{2}$ values and very high DOC content. This is due to the more recalcitrant nature of DOC leached from old peat soils, and to the rapid evasion of $\mathrm{CO}_{2}$ to the atmosphere in these fast flowing waters (Hope et al., 2001; Billet et al., 2004). In lakes, DOC is negatively correlated with water residence time, showing the predominant role of microbial and photochemical oxidation (Tranvik, 2005). In some temperate eutrophic rivers, a seasonal and sometimes annual uptake of atmospheric $\mathrm{CO}_{2}$ is observed (Fig. 6). Atmospheric carbon fixed by aquatic primary production is then transported downstream as organic carbon. The Loire River, for instance, transports large quantities of algal carbon which are mineralized in the estuarine turbidity maximum, leading to high $\mathrm{CO}_{2}$ degassing (Meybeck et al., 1988; Abril et al., 2004). In fact, many European macrotidal estuaries behave as "hotspots" for $\mathrm{CO}_{2}$ degassing, owing to the quantity of organic carbon they receive and to the long residence time of waters and suspended sediments (Frankignoulle et al., 1998; Abril et al., 2002; Abril and Borges 2004). The relative scarcity of $p \mathrm{CO}_{2}$ data in continental waters, and the high spatial and temporal variability, renders a bottom-up estimate at the EU-25 scale rather uncertain. In addition, the surface areas of some ecosystems are uncertain and the highest $\mathrm{CO}_{2}$ fluxes occur in ecosystems with the smallest surface areas (estuaries and rivers).

4.4 River carbon transport and the European carbon bal-
ance

The lateral transport of river carbon was compiled using the main European rivers database (Meybeck and Ragu, 1996) and extrapolated for the European seas catchment $\left(8.1610^{6} \mathrm{~km}^{2}\right)$ and the EU-25 on the basis of runoff, land cover and rock types similarities. Estuarine filters are included in this calculation (Abril and Meybeck, in preparation). Southern, central and northern European rivers show marked diversity in export rates and carbon species (Table 3). Table 2 compares the order of magnitude of the lateral carbon transport in rivers with the outgassed $\mathrm{CO}_{2}$ flux. Fluxes of $\mathrm{CO}_{2}$ from freshwater sub-ecosystems in peatland streams, lakes, rivers, and estuaries are compiled from published $p \mathrm{CO}_{2}$ distributions, using typical gas transfer velocities and information on surface areas of sub-ecosystems (Abril and Meybeck, in preparation). Because river transport is based on non-tidal river sampling and is calculated for the entrance of estuaries (Table 3), $\mathrm{CO}_{2}$ degassing in freshwaters and in estuaries are distinguished in Table 2. Overall, European rivers transport laterally $53 \mathrm{Tg} \mathrm{C} \mathrm{yr}^{-1}$ to estuaries, and they emit $90 \mathrm{Tg} \mathrm{C} \mathrm{yr}^{-1}$ of $\mathrm{CO}_{2}$ to the atmosphere (Table 2). A majority of the degassing occurs at northern latitudes. Despite their lower $\mathrm{CO}_{2}$ flux density, lakes contribute up to $35 \%$ of the total $\mathrm{CO}_{2}$ freshwater degassing (excluding wetlands and estuaries) owing to their large surface area (183 $10^{3} \mathrm{~km}^{2}$ in total) despite their lower $\mathrm{CO}_{2}$ flux density. $\mathrm{CO}_{2}$ degassing from European estuaries has been previously estimated to $30-60 \mathrm{Tg} \mathrm{C} \mathrm{yr}^{-1}$ (Frankignoulle et al., 1998). This range is probably an overestimate for two reasons: (1) the surface area of European estuaries used by Frankigoulle et al., $\left(112 \times 10^{3} \mathrm{~km}^{2}\right)$ was much higher than recent estimates $\left(36 \times 10^{3} \mathrm{~km}^{2}\right)$ from the Global Lakes and Wetlands Database of Lehner and Döll (2004), and (2) the investigated estuaries were mainly macrotidal, wherein net heterotrophy and $\mathrm{CO}_{2}$ degassing were favored (Abril and Borges 2004; Borges et al., 2006). Little or no $\mathrm{CO}_{2}$ data are available for fjords, fjärds, deltas and coastal lagoons. Scaling up the available $\mathrm{CO}_{2}$ flux estimates to the surface area of coastal wetlands and estuaries from Global Lakes and Wetlands Database gives a $\mathrm{CO}_{2}$ source estimate of 10$20 \mathrm{Tg} \mathrm{C} \mathrm{yr}^{-1}$. This value is similar to the estimate of organic carbon transported by European rivers up to the estuarine filter of $20 \mathrm{Tg} \mathrm{C} \mathrm{yr}^{-1}$ (Table 3). 
Table 3. Fluxes and origin of river carbon fluxes reaching the continental shelf after estuarine filters. Irrigation is not taken into account. By convention a negative sign is given to fluxes representing $\mathrm{C}$ initially withdrawn from the atmosphere by plant $\mathrm{CO}_{2}$ uptake.

\begin{tabular}{llllllll}
\hline & $\begin{array}{l}\text { Drainage area } \\
\left(10^{3} \mathrm{~km}^{2}\right)\end{array}$ & $\begin{array}{l}\text { Water flow } \\
\left(\mathrm{km}^{3} \mathrm{yr}^{-1}\right)\end{array}$ & $\begin{array}{l}\text { River carbon } \\
\left(\mathrm{Tg} \mathrm{C} \mathrm{y}^{-1}\right)\end{array}$ & $\begin{array}{l}\text { Carbon yield } \\
\left(\mathrm{g} \mathrm{C} \mathrm{m}^{-2} \mathrm{yr}^{-1}\right)\end{array}$ & $\begin{array}{l}\text { DOC } \\
(\%)\end{array}$ & $\begin{array}{l}\text { POC } \\
(\%)\end{array}$ & $\begin{array}{l}\mathrm{DIC}^{\mathrm{a}} \\
(\%)\end{array}$ \\
\hline $\begin{array}{l}\text { Northern Europe } \\
\left(>50^{\circ} \mathrm{N}\right)\end{array}$ & 2528 & 806 & -13.6 & -5.4 & 54.3 & 4.4 & 41.1 \\
$\begin{array}{l}\text { Temperate Europe } \\
\left(42-50^{\circ} \mathrm{N}\right)\end{array}$ & 4699 & 1188 & -24.5 & -5.2 & 23.3 & 9.0 & 67.6 \\
$\begin{array}{l}\text { Southern Europe } \\
\left(<42^{\circ} \mathrm{N}\right)\end{array}$ & 936 & 360 & -10.2 & -10.8 & 9.2 & 11.5 & 79.2 \\
Total Europe & 8163 & 2355 & -48.3 & -5.9 & 29.1 & 8.3 & 62.6 \\
\hline
\end{tabular}

${ }^{\text {a }}$ percent of total carbon in DIC of atmospheric origin.

\section{Coastal seas}

Coastal seas receive nutrient and organic matter inputs from estuaries, and exchange water and matter with the open ocean waters across marginal slopes. For European coastal seas, the gross water fluxes across marginal slopes are 250-2000 times larger than the fresh water input (Huthnance, 2008). Carbon in coastal waters also depends on the carbon content, which strongly decrease between estuaries and the open ocean. Nevertheless, the inputs of carbon from the open ocean to the coastal seas are significant because of the much higher water fluxes involved. In the North Sea, the inputs of DOC and DIC through the northern boundary of the North Atlantic Ocean are, respectively, 45 and 140 times higher than from estuaries. The input of the same species from the Baltic Sea is roughly equivalent to those from estuaries. The input of DOC and DIC from the English Channel are, respectively, 3 and 13 times higher than the inputs from estuaries (Thomas et al., 2005).

Unlike macrotidal estuaries which emit $\mathrm{CO}_{2}$ to the atmosphere throughout the year (see Sect. 4.4), coastal seas usually exhibit a distinct seasonal cycle of air-sea $\mathrm{CO}_{2}$ fluxes. They shift from a $\mathrm{CO}_{2}$ source to a sink, depending on biological activity. The coastal air-sea fluxes are hence predominantly controlled by the net ecosystem production NEP. This is illustrated in Fig. 7 for the Southern Bight of the North Sea. This region acts as a sink of $\mathrm{CO}_{2}$ in April-May during the phytoplankton blooms, and as a source during the rest of the year due to the degradation of organic matter. However, on an annual basis it is a net sink of atmospheric $\mathrm{CO}_{2}$ due to the seasonal decoupling of organic matter production and degradation, with a probable export of organic matter to the adjacent areas.

Besides $N E P$, air-sea $\mathrm{CO}_{2}$ fluxes in coastal seas are also modulated by $\mathrm{CaCO}_{3}$ precipitation/dissolution, decoupling of carbon production and degradation within the water column in presence of stratification, temperature and salinity

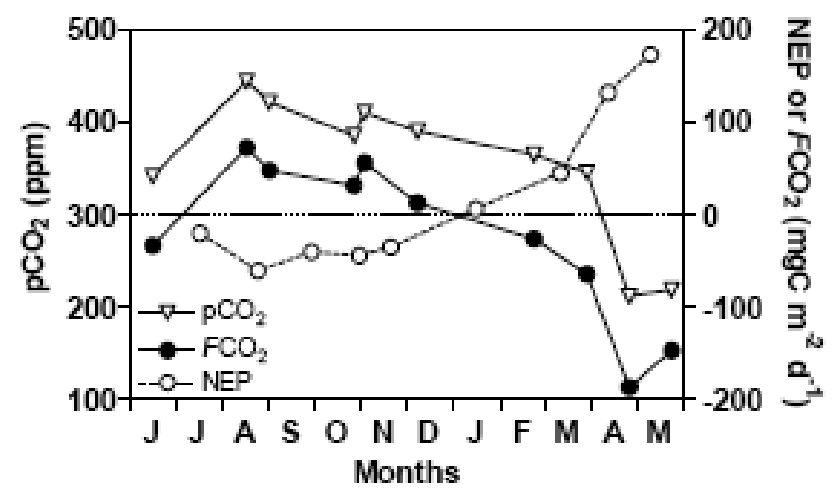

Fig. 7. Annual cycle (June 2003-May 2004) of net ecosystem production (NEP in $\mathrm{m} \mathrm{g} \mathrm{C} \mathrm{m-2} \mathrm{d-1),} \mathrm{air-sea} \mathrm{CO}_{2}$ fluxes $\left(\mathrm{FCO}_{2}\right.$ in $\mathrm{m} \mathrm{g} \mathrm{C} \mathrm{m-2} \mathrm{d-1)} \mathrm{and} \mathrm{the} \mathrm{partial} \mathrm{pressure} \mathrm{of} \mathrm{CO}_{2}\left(p \mathrm{CO}_{2}\right)$ in the Southern Bight of the North Sea (adapted from Schiettecatte et al., 2006).

changes, Revelle factor, exchange of water with adjacent aquatic systems, water residence times (Borges et al., 2005, 2006). Figure 8 shows the annually integrated air-sea $\mathrm{CO}_{2}$ flux of various European coastal seas. The spatial heterogeneity is clearly apparent. Seasonal patterns also differ from one coastal sea to another (Borges et al., 2005, 2006). In general, we estimate that the European coastal seas are a net $\mathrm{CO}_{2}$ sink of atmospheric of $68 \mathrm{Tg} \mathrm{C} \mathrm{yr}^{-1}$, with an uncertainty of $20 \%$. This value is equivalent to $60 \%$ of the continental wide European carbon sink of $111 \pm 279 \mathrm{Tg} \mathrm{C} \mathrm{yr}^{-1}$ (Janssens et al., 2005). 


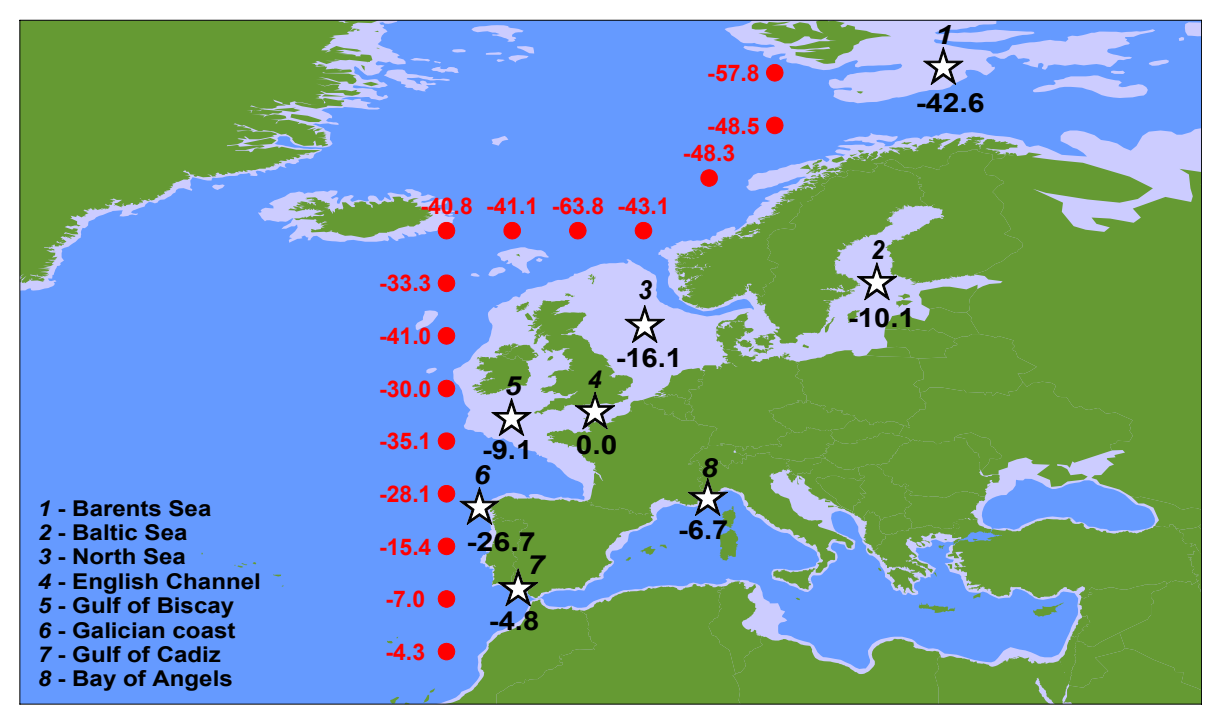

Fig. 8. Compilation of annually integrated air-sea $\mathrm{CO}_{2}\left(\mathrm{~g} \mathrm{C} \mathrm{m}^{-2} \mathrm{yr}^{-1}\right)$ fluxes in European coastal seas (stars and black numbers) (adapted from Borges et al., 2006) and adjacent open ocean grid nodes from the Takahashi et al. (2002) air-sea flux climatology (red circles and numbers).

\section{Discussion}

\subsection{Lateral carbon transport at diverse scales}

The carbon budget of a continent is more complex than just the sum of photosynthesis, respiration, combustion, and anthropogenic fluxes. Key processes transport carbon away from ecosystems where it was fixed by photosynthesis, with resultant increased variability in estimates for temporal storage and transformation. Carbon can be transported horizontally over long distances (100-1000 km), but eventually becomes oxidized and is released back to the atmosphere as $\mathrm{CO}_{2}$, thus closing the cycle initiated by photosynthesis. This is illustrated in Fig. 1 for three lateral transport processes: crop and wood product trade, reduced carbon compounds atmospheric transport and river carbon fluxes. Within the EU-25 territory, lateral transport creates and accentuates regional imbalances between $\mathrm{CO}_{2}$ sinks and $\mathrm{CO}_{2}$ sources. At the continental level, the transport of carbon by rivers, by trade and by the atmospheric RCC fluxes results in a net $\mathrm{CO}_{2}$ sink, balanced by a source elsewhere in the world. In atmospheric $\mathrm{CO}_{2}$ flux inversions, ignoring the patterns of $\mathrm{CO}_{2}$ fluxes due to lateral transport may bias the inferred continental-scale flux. When comparing different approaches to quantify regional carbon budgets, methods based on carbon stock changes (forest biomass and soil carbon inventories) will have to be corrected from lateral fluxes in order to be compared with methods based on $\mathrm{CO}_{2}$ flux observations (eddy covariance, atmospheric inversions). At the continental scale, the correction of carbon stocks changes into $\mathrm{CO}_{2}$ fluxes, is of the same magnitude as the mean $\mathrm{CO}_{2}$ flux estimate itself (Table 2)! At the local scale, due to imbal- ance between respiration and photosynthesis, this correction can be very large as well, especially over croplands and managed forests from which carbon is harvested. At the regional scale, the impact of the trade of food and wood products on $\mathrm{CO}_{2}$ fluxes is diverse. Northern countries tend to be larger sinks and southern countries larger sources of $\mathrm{CO}_{2}$, due to food and wood trade.

The main implication of lateral carbon fluxes in the context of carbon trading is that measurement of vertical $\mathrm{CO}_{2}$ fluxes exchanged with the atmosphere do not exactly match measurement of ecosystem stock changes. The question is thus to assess the fate of this missing carbon entrained in lateral transport circuits. Carbon transported in food trade will be oxidized in a year, and should not be counted as a sink globally. A fraction of carbon transported in wood trade will form a long-term sink into long-lived products. Should this carbon sink be credited to the host country or to the country of origin for the wood? For instance, a given carbon credit could be attached to the exported wood. A fraction of the carbon transported by rivers originates from rocks, being part of the slow geological carbon cycle. This background flux should correspond to no carbon credit. The remainder of river carbon originates from ecosystems, but can have different lifetimes through the river filters, being either degassed to the atmosphere within less than a year, or sequestered in long-lived organic sediments. Our calculations suggest that a minimum fraction of $70 \%$ of the ecosystem carbon transported by European rivers is returned rapidly to the atmosphere (Table 2).

\subsection{Lateral carbon fluxes at the continental level}

At the continental level, food and forest product trade fluxes result only in a small net source of $\mathrm{CO}_{2}$ to the atmosphere 


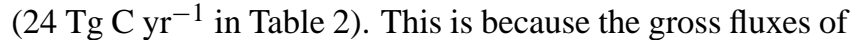
import implying a $\mathrm{CO}_{2}$ source, and the one of export implying a $\mathrm{CO}_{2}$ sink where the exported biomass is grown, are approximately in balance. We found that the gross flux of carbon released to the atmosphere in the form of RCC is large (185 $\mathrm{Tg} \mathrm{C} \mathrm{yr}^{-1}$ ), about $15 \%$ of the annual fossil fuel $\mathrm{CO}_{2}$ emissions in EU-25. The impact of RCC on the net carbon balance of Europe is complex (Table 2) because a fraction of the RCC emissions is rapidly oxidized into $\mathrm{CO}_{2}$ in the boundary layer, while another fraction is re-deposited at the surface. Overall, we estimate that RCC cause a net carbon source of $76 \mathrm{Tg} \mathrm{C} \mathrm{yr}^{-1}$ over the continent but correspond to a net $\mathrm{CO}_{2}$ sink of $61 \mathrm{Tg} \mathrm{C} \mathrm{yr}^{-1}$. This difference in sign illustrates the fact that $\mathrm{C}$ fluxes differ significantly from $\mathrm{CO}_{2}$ fluxes. The riverine transport of atmospheric carbon from ecosystems into the estuaries must be fueled at steady state

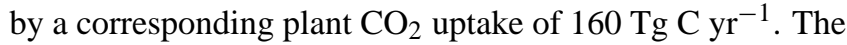
magnitude of this $\mathrm{CO}_{2}$ uptake is large when compared to the net carbon storage of European ecosystems of $111 \mathrm{Tg} \mathrm{C} \mathrm{yr}^{-1}$, Janssens et al. (2003). A large fraction (76\%) of carbon transported by rivers is outgassed to the atmosphere in waterscapes or buried in lakes, dam and estuarine sediments, while the rest is delivered to inner estuaries. At the level of estuaries, a further outgassing of $\mathrm{CO}_{2}$ will occur. Overall, we estimate that the river transport of carbon implies a net $\mathrm{CO}_{2}$ sink over ecosystems at the continental scale $\left(60 \mathrm{Tg} \mathrm{yr}^{-1}\right.$ in Table 2) while almost the same amount gets exported to the oceans in a dissolved or particulate form (Table 2). The reason why the land $\mathrm{CO}_{2}$ sink does not match exactly the export flux exported to the ocean is because a small fraction of the river carbon is coming from rocks (Table 2).

\subsection{Coastal seas and lateral carbon fluxes}

We included coastal seas in the analysis, because they receive a "lateral" carbon flux from the continents and because coarse-resolution atmospheric inversions encompass coastal seas in their estimate of what is usually called the European $\mathrm{CO}_{2}$ flux. European coastal seas are net sinks for atmospheric $\mathrm{CO}_{2}$, in the range of $100 \mathrm{Tg} \mathrm{C} \mathrm{yr}^{-1}$. This coastal $\mathrm{CO}_{2}$ sink is comparable in magnitude to the terrestrial carbon uptake by ecosystems $\left(111 \pm 279{\mathrm{Tg} \mathrm{C} \mathrm{yr}^{-1}}^{-}\right.$, Janssens et al., 2003). Coastal seas are $\mathrm{CO}_{2}$ sinks despite the fact that they receive a flux of carbon from rivers of $53 \mathrm{Tg} \mathrm{C} \mathrm{yr}^{-1}$ (Table 3). This is because the fluxes exchanged with the adjacent open oceans are controlling the budget of coastal seas. The $\mathrm{CO}_{2}$ fluxes of coastal seas are significantly different from those in the adjacent open ocean (from Takahashi et al., 2002). The latter is commonly used in atmospheric $\mathrm{CO}_{2}$ inversion models, which likely will lead to a significant (but not yet quantified) bias in the flux estimates derived by these models. In particular, large biases are expected for terrestrial regions adjacent to extensive coastal seas, such as the Gulf of Biscay and the North Sea.

\section{Conclusions}

The lateral carbon fluxes induced by crop and forest product trade, atmospheric oxidation and atmospheric transport of RCC and river transport are important contributors to the carbon budget of EU-25, at the regional and continental level. At the continental level, we estimate that lateral transport fluxes amount to $165 \mathrm{Tg} \mathrm{C} \mathrm{yr}^{-1}$, including the carbon sink of coastal seas. Most of this lateral flux consists of RCC emitted to the atmosphere and exported out of Europe by winds. The RCC emission requires a $\mathrm{CO}_{2}$ photosynthetic uptake of equivalent magnitude, hence being larger than the biomass accumulation in forests deduced from inventories. Including this $\mathrm{CO}_{2}$ photosynthetic uptake which is used to make $\mathrm{RCC}$, doubles the imbalance between photosynthesis and ecosystem respiration of European forests. In this work, we only attempted to estimate lateral transport processes at the continental level, but these fluxes should also be taken into account at the site and regional levels, for instance to reconcile eddy covariance estimates of the $\mathrm{CO}_{2}$ fluxes and biometric measurements of changes in biomass and soil carbon stocks. This work also demonstrates that a substantial amount of carbon is displaced in proportion to the NPP, roughly about $10 \%$ of the NPP of the EU-25 territory.

Lateral carbon transport may also explain why inverse modeling estimates of the $\mathrm{CO}_{2}$ sink are nearly always systematically higher than forest inventory numbers of carbon stock changes. Maps of $\mathrm{CO}_{2}$ sinks required to match lateral transport fluxes should be accounted for in inversion studies, for instance by prescribing an adapted a priori flux structure. In future work, investigations of lateral carbon fluxes should also reflect changes in economic and land use drivers in the context of implications for future climate change.

Acknowledgements. The authors wish to acknowledge support from the CARBOEUROPE Integrated Project, and the CARBOEUROPE-GHG Concerted Action, both projects funded by the EU.

Edited by: J.-P. Gattuso

\section{References}

Abril, G. and Borges, A. V.: Carbon dioxide and methane emissions from estuaries. In Greenhouse Gas Emissions: Fluxes and Processes. Hydroelectric Reservoirs and Natural Environments, edited by: Tremblay, A., Varfalvy, L., Roehm, C., and Garneau, M., Environmental Science Series, Springer-Verlag, Berlin, Heidelberg, New York, 187-207, 2004.

Abril, G., Etcheber, H., Borges, A. V., and Frankignoulle, M.: Excess atmospheric carbon dioxide transported by rivers into the Scheldt Estuary. Comptes Rendus de l'Académie des Sciences, Série IIA 330, 761-768, 2000.

Abril, G., Nogueira, M., Etcheber, H., Cabeçadas, G., Lemaire, E., and Brogueira, M. J.: Behaviour of organic carbon in nine 
contrasting European estuaries. Estuarine, Coastal and Shelf Science, 54, 241-262, 2002.

Anthoni, P., Freibauer, A., Kolle, O., and Schulze, E.-D.: Winter wheat carbon exchange in Thuringia, Germany, Agricultural and Forest Meteorology, 121, 55-67, 2004.

Aucour, M. A., Sheppard, S. M. F., Guyomar, O. and Wattelet, J.: Use of ${ }^{13} \mathrm{C}$ to trace origin and cycling of inorganic carbon in the Rhône river system, Chemical Geology, 159, 87-105, 1999.

Aumont, O., Orr, J. C., Monfray P., Ludwig, W., Amiotte-Suchet, P. and Probst, J. L.: Riverine-driven interhemispheric transport of carbon, Glob. Biogeochem. Cy., 15, 393-405, 2001.

Billett, M. F., Palmer, S. M., Hope, D., Deacon, C., StoretonWest, R., Hargreaves, K. J., Flechard, C., and Fowler, D.: Linking land-atmosphere-stream carbon fluxes., Global Biogeochem. Cy., 18(1), 1-12, 2004.

Borges, A. V., Delille, B., Schiettecatte, L. S., Gazeau, F., Abril, A., and Frankignoulle, M.: Gas transfer velocities of $\mathrm{CO}_{2}$ in three European estuaries (Randers Fjord, Scheldt and Thames), Limnol. Oceanogr., 49(5), 1630-1641, 2004.

Borges, A. V.: Do we have enough pieces of the jigsaw to integrate $\mathrm{CO}_{2}$ fluxes in the Coastal Ocean?, Estuaries, 28(1), 3-27, 2005.

Borges, A. V., Delille, B., and Frankignoulle, M.: Budgeting sinks and sources of $\mathrm{CO}_{2}$ in the coastal ocean: Diversity of ecosystems counts., Geophys. Res. Lett., 32, L14601, doi:10.1029/2005GL023053, 2005.

Borges, A. V., Schiettecatte, L. S., Abril, G., Delille, B., and Gazeau, F.: Carbon dioxide in European coastal waters, Estuarine Coastal and Shelf Science, 70, 375-387, 2006.

Ciais, P., Bousquet, P. Freibauer, A., and Naegler, T.: On the horizontal displacement of carbon associated to agriculture and how it impacts atmospheric $\mathrm{CO}_{2}$ gradients, Global Biogeochem. Cy., 21, GB2014, doi:10.1029/2006GB002741, 2007.

Cole, J. J. and Caraco, N. F.: Carbon in catchments: connecting terrestrial carbon losses with aquatic metabolism, Marine Freshwater Res. 52, 101-110, 2001.

Cole, J. J., Caraco, N. F., Kling, G. W., and Kratz., T. W.: Carbon dioxide supersaturation in the surface waters of lakes, Science, 265, 1568-1570, 1994.

CORINE Land cover: EEA online publications: http://reports.eea. eu.int/COR0-landcover/en., 2000.

Enting, I. G. and Mansbridge, J. V.: Latitudinal Distribution of Sources and Sinks of $\mathrm{CO}_{2}$ - Results of an Inversion Study, Tellus, 43B, 156-170, 1991.

FAO, Food and Agriculture Organization Agricultural Database, in http://apps.fao.org/page/collections?subset=agriculture, 2004.

Folberth, G., Hauglustaine, D., Ciais, P., and Lathière, J.: On the role of atmospheric chemistry in the global $\mathrm{CO}_{2}$ budget, Geophys. Res. Lett., 32, L08801, doi:10.1029/2004GL021812, 2005.

Frankignoulle M., Abril, G., Borges, A., Bourge, I., Canon, C., Delille, B., Libert, E., and Théate, J. M.: Carbon dioxide emission from European estuaries., Science, 282, 434-436, 1998.

Gazeau, F., Gattuso, J. P., Middelburg, J. J., Brion, N., Schiettecatte, L.-S., Frankignoulle, M., and Borges, A. V.: Planktonic and whole system metabolism in a nutrient-rich estuary (the Scheldt Estuary), Estuaries, 28(6), 868-883. 2005.

Graneli, W., Lindell, M., and Tranvik L.: Photo-Oxidative Production of Dissolved Inorganic Carbon in Lakes of Different Humic Content., Limnol. Oceanogr., 41, 698-706, 1996.

Goudriaan, J., Groot, J. R., and Uithol, P. W. J.: Productivity of
Agro-ecosystems, in Terrestrial Global Productivity, edited by: Roy, J., Saugier, B. and Mooney, H. A., Academic Press, 2001.

Grosbois, C., Négrel, P., Fouillac C., and Grimaud, D.: Dissolved load of the Loire River: chemical and isotopic characterization., Chem. Geol., 170, 179-201, 2000.

Hauglustaine, D. A., Hourdin, F., Jourdain, L., Filiberti, M. A., Walters, S., Lamarque, J. F., and Holland, E. A.: Interactive chemistry in the Laboratoire de Météorologie Dynamique general circulation model: Description and background tropospheric chemistry evaluation, J. Geophys. Res., 109, S=D04314, doi:10.1029/2003JD003957, 2004.

Hope, D., Palmer, S., Billet, M., and Dawson, J. J. C.: Carbon dioxide and methane evasion from a temperate peatland stream., Limnol. Oceanogr., 46, 847-857, 2001.

Huthnance, J. M.: North-East Atlantic margins, in: Carbon and Nutrient Fluxes in Global Continental Margins, edited by: Liu, K. K., Atkinson, L., Quinones, R., and Talaue-McManus, L., Springer-Verlag, New York, 2008.

Imhoff, M. L., Bounoua, L., Ricketts, T., Loucks, C., Harriss,R., and Lawrence, W. T.: Global patterns in human consumption of net primary production, 429, 870-873, 2004.

Janssens, I. A., Freibauer, A., Ciais, P., Smith, P., Nabuurs, G., Schlamadinger, B., Hutjes, R., Schulze, E., Ceulemans, E., Valentini, R., and Dolman, J.: Europe's terrestrial biosphere absorbs 7 to $12 \%$ of European Anthropogenic emissions, Science, 300, 1538-1542, 2003.

Janssens, I. A., Freibauer, A., Schlamadinger, B., Ceulemans, R., Ciais, P., Dolman, A. J., Heimann, M., Nabuurs, G. J., Smith, P., Valentini, R., Schulze, E. D.: The carbon budget of terrestrial ecosystems at country-scale - a European case study, Biogeosciences, 2, 15-26, 2005, http://www.biogeosciences.net/2/15/2005/.

Jones, J. B. and Mulholland, P. J.: Carbon dioxide variation in a hardwood forest stream: an integrative measure of whole catchment soil respiration, Ecosystems, 1, 183-196, 1998.

Kempe, S.: Long term record of $\mathrm{CO}_{2}$ pressure fluctuations in freshwaters., Mitteilungen aus dem Geologish-Paläontologishen, Institut der Universität Hamburg, 52, 91-332, 1982.

Kempe, S.: Sinks of the anthropogenically enhanced carbon cycle in surface fresh waters, J. Geophys. Res., 89, 4657-4676, 1984.

Kesselmeier, J., Ciccioli, P., Kuhn, U., Stefani, P., Biesenthal, T., Rottenberger, S., Wolf, A., Vitullo, M., Valentini, R., Nobre, A., Kabat, P., and Andreae, M. O.: Volatile organic carbon compound emissions in relation to plant carbon fixation and the terrestrial carbon budget, Global. Biogeochem. Cy., 16, 1126-1134, 2005.

Lafont, S., Kergoat, L., Dedieu, G., Chevillard, A., Karstens, U., and Kolle, O.: Spatial and temporal variability of land $\mathrm{CO}_{2}$ fluxes estimated with remote sensing and analysis data over western Eurasia, Tellus, 54B, 820-833, 2002.

Liski, J., Palosuo, T., Peltoniemi, M., and Sievänen, R.: Carbon and decomposition model Yasso for forest soils., Ecological Modelling, 189(1-2), 168-182, 2005.

Ludwig, W., Meybeck, M., and Abousamra, F.: Riverine transport of water, sediments and pollutants to the Mediterranean Sea, in: Medit. Action Technical Report Series \#141, UNEP/MAP Athens, 111 pp., 2003.

Meybeck, M.: Riverine transport of atmospheric carbon: sources, global typology and budget, Water, Air Soil Pollution, 70, 443- 
464, 1993.

Meybeck, M.: Global distribution and behaviour of carbon species in world rivers, in: Soil Erosion and Carbon dynamics, edited by: Roose, E., Lal, R., Feller, C., Barthès, B., and Stewart, B. A., Advances in Soil Science Series, CRC Boca Raton, 209-238, 2005.

Meybeck, M. and Ragu, A.: River Discharges to the Oceans, An assessment of suspended solids, major ions, and nutrients, in: Environment Information and Assessment Rpt. UNEP, Nairobi, p. 250, 1996.

Meybeck, M., Cauwet, G., Dessery, S., Somville, M., Gouleau, D., and Billen G.: Nutrients (Organic C, P, N, Si) in the eutrophic river Loire and its estuary. Estuarine Coastal Shelf Sciences, 27, 595-624, 1988

Myneni, R., Dong, J., Tucker, C., Kaufmann, R. K., Kauppi, P. E., Uski, J., Zhou, L., Alexeyev, V., and Hughes, M. K.: A large carbon sink in the woody biomass of Northern forests, Proc. Natl. Acad. Sciences, 14 784-14 789, 2001.

Neal, C., House, W. A., Jarvie, H. P., and Eatherall, A.: The significance of dissolved carbon dioxide in major rivers entering the North Sea, The Science of the total environment 210/211, 187203, 1998.

Pacala, S. W., Hurtt, G. C., Baker, D., Peylin, P., Houghton, R. A., Birdsey, R. A., Heath, L., Sundquist, E. T., Stallard, R. F., Ciais, P., Moorcroft, P., Caspersen, J. P., Shevliakova, E., Moore, B., Kohlmaie, G., Holland, E., Gloor, M., Harmon, M. E., Fan, S.M., Sarmiento, J. L., Goodale, C. L., Schimel, D., and Field, C. B.: Consistent Land- and Atmosphere-Based US Carbon Sink Estimates, Science, 292, 2316-2320, 2001.

Peylin, P., Bousquet, P., LeQuéré, C., Sitch, S., Friedlingstein, P., McKinley, G. A., Gruber, N., Rayner, P., and Ciais, P.: Multiple constraints on regional $\mathrm{CO}_{2}$ fluxes variations over land and oceans, Global Biogeochem. Cy., 19, GB1011, doi:10.1029/2003GB002214, 2005.

Prentice, I. C., Farquhar, G. D., Fasham, M. J. R., et al.: The carbon cycle and atmospheric carbon dioxide, in: Climatic Change 2001: The Scientific Basis, Contribution of Working Group I to the Third Assessment Report of the Intergovernmental Panel on Climate Change, 185-225, Cambridge University Press, Cambridge, 2001
Ramankutty, N. and Foley, J.: Characterizing patterns of global land use: An analysis of global croplands data, Global Biogeochem. Cy., 12, 667-685, 1998.

Sarmiento, J. L. and Sundquist, E. T.: Revised budget for the oceanic uptake of anthropogenic carbon dioxide, Nature, 356 , 589-593, 1992.

Schiettecatte, L. S., Thomas, H., Bozec, Y., and Borges, A. V.: High temporal coverage of carbon dioxide measurements in the Southern Bight of the North Sea, Marine Chemistry, Marine Chemistry, 106(1-2), 161-173, 2007.

Sobek, S., Algesten, G., Bergstrom, A.-K., Jansson, M., Tranvik, L. J.: The catchment and climate regulation of $p \mathrm{CO}_{2}$ in boreal lakes., Global Change Biology, 9, 630-41, 2003.

Takahashi, T., Sutherland, S. C., Sweeney, C., Poisson, A., Metzl, N., Tilbrook, B., Bates, N. R., Wanninkhof, R., Feely, R. A., Sabine, C., Olafsson, J., and Nojiri, Y.: Global sea-air $\mathrm{CO}_{2}$ flux based on climatological surface ocean $p \mathrm{CO}_{2}$, and seasonal biological and temperature effects, Deep-Sea Res. II, 49(9-10), 1601-1622, 2002.

Tans, P. P., Fung, I. Y., and Enting, I. G.: Storage versus flux budgets: the terrestrial uptake of $\mathrm{CO}_{2}$ during the 1980s, In Biotic feedbacks in the global system, edited by: Woodwell, G. M. and Mackenzie, F. T., 351-366, Oxford University Press, New York, 1995.

Thomas, H., Bozec, Y., De Baar, H. J. W., Elkalay, K., Frankignoulle, M., Schiettecatte, L.-S., and Borges, A. V.: The carbon budget of the North Sea., Biogeosciences, 2(1), 87-96, 2005.

Tranvik, L.: Terrestrial dissolved organic matter - a huge but not unlimited subsidy to aquatic ecosystems, Proceedings of ASLO summer meeting, Santiago de Compostella, 19-24 June 2005.

Vörösmarty, C. J., Meybeck, M., Fekete, B., Sharma, K., Green, P., and Syvitski, J.: Anthropogenic sediment retention: major global-scale impact from the population of registered impoundments, Global Planetary Changes, 39, 169-190, 2003.

Wanninkhof, R., Mulholl, P. J., and Elwood, J. W.: Gas exchange rates for a first order stream determined with deliberate and natural tracers, Water Resources Res., 26, 1621-1630, 1990. 